\title{
Hearing Prosthetics: Digital Signal Processing in Patients with Central Auditory Processing Deficit
}

\author{
Valeria Serra* \\ Department of Postgraduate Specialty in Audiology, University of the Argentine Social Museum
}

Submission: May 03, 2017; Published: May 24, 2017

*Corresponding author: Valeria Serra, Department of Postgraduate Specialty in Audiology, University of the Argentine Social Museum, Graduate in Speech Therapy (National University of Rosario) - Rosario - Mat.:102Mat. RE: 001 L.I F, Office: San Luis 3407 - Santa Fe - Argentina,

Tel. /Fax: 00543424810018

\section{Introduction}

High-tech digital hearing aids allow greater versatility when implementing signal programming strategies. The digital signal processing capability makes it possible to implement individual adaptation modalities through different prescriptive methods, adaptive directionality, activation at various compression points, noise attenuators, binaural coordination, and so on. Which contribute to auditory dynamics. Modern audiology cannot be understood as unrelated to neuroscience. Advances in the understanding of the functioning of the neurons and the circuits in which they are assembled, PA (C): Central Auditory processing, allow a better understanding of the pathology also: Central Auditory Deficit - DPA (C) [1-30]. Thus the development of technologies offers an unprecedented view on the functioning of the brain and the auditory structures, which have allowed deciphering puzzles quickly and beginning to have relevant data on how these structures and their biological mechanisms intervene in hearing in normal situations and Pathological conditions [31].

The professionals of the hearing aids and of the audiology have to be provided with knowledge of the intimate mechanisms that, at the cellular and molecular level, allow the auditory neural circuits to adapt to situations of deficient processing, as it happens in the DPA (C), Understanding the adaptive plastic mechanisms and how they are produced $[32,33]$, as well as these professionals must have sufficient competence to manipulate the available technology, that through digital signal processing, collaborate in the intervention, new therapeutic and / or preventive approaches that tend Maintain the biological balance of the system [34-50].

\section{General and Specific Objective}

This paper aims to propose different procedures for digital signal processing of current hearing aids, and how these could intervene favoring, stimulating and providing complementary information in auditory training when used in patients with APD
(C) $[51-60]$.

Specific objectives are:

a) Recognize and explain mechanisms that support the CNS and auditory cortex functions.

b) Define PA (C).

c) Characterize the Central Auditory Processing and the skills it supports.

d) Consider criteria for the selection of DPA (C) in patients with peripheral hearing loss.

e) Define DPA (C) .Affected skills.

f) Conceptualize: digital signal processing.

g) Conceptualize specific terminology and explain the functions that incorporate state-of-the-art digital hearing aids.

h) Associate electroacoustic characteristics of the latest generation hearing aids that digitally process the signal, with aspects of the intervention in patients with APD (C)

\section{Conclusion}

A great deal of research carried out in the field of neuroscience in the last decade has generated as a result many answers to central topics for understanding the functioning of the brain. From the bibliographical data collected for the elaboration of this work the following conclusions are drawn [60]:

a. The auditory cortex is part of the cerebral cortex that is part of the Central Nervous System (CNS), so the functional mechanisms that underlie its activity are identical to those that apply to the processes that occur at the level of the auditory cortex.

b. In the development of the Auditory System, via auditory and cortex, reciprocal influences are recognized between 
the auditory neural structures at the level of the cortex and the cochlear formation.

c. The neural structures of the auditory cortex influence the formation of the cochlea in a first stage of development (centrifugal influence), a posteriori in the late embryonic stage, the fetal period and the first months of life the influence of the sound stimuli transmitted by The cochlea, condition the maturation of the nervous centers of the acoustic path (centripetal influence) [60-70].

d. The functionality of the cortex is based on various forms of communication between neurons. These synapses are chemical transmission processes that occur at the cellular level (neurotransmission), which through mechanisms of excitation and neuronal inhibition tend to maintain a bioelectric balance of NS [71-75].

e. Neurons tend to be grouped according to their specificity for a given function (for example: the auditory function). The information transmitted between the neurons is organized in an organized way, hierarchical in parallel with an interactive communication that is maintained with different levels of the central nervous system (Parallel Distributed Processing model). These functional networks have a resolutive modality, that is to say that in front of the deficit of a certain component they allow that the necessary modifications are restored to restore the function.

f. The remodeling, reorganization, establishment of new neural connections (synapses) is possible thanks to the plastic capacity of the brain to modify or adapt to changes.

g. Although controversial subjects within neuroscience, while recognizing a critical period of greater neuronal plasticity, around the first twenty-four to thirty-six months of life, several studies show that there are certain regions of the brain in which development Neuronal phenomenon also occurs in adult life and is influenced by stimulation [76].

h. It is recognized that cerebral plasticity is manifested both in CNS intimate processes, as happens at the cellular level with neurotransmission, particularly in modifications that affect the chemical receptors involved in this communication, as is also evidenced in the conformation of New synapses, overlapping circuits and functional networks.

i. The SN's ability to adapt to changes in the environment or new situations, entails learning new functions, and the ability to learn is based on the constitution of new circuits.

j. Neuroplasticity understood in the context of functional learning is one of the main mechanisms through which the species evolve; Depend on the interaction of the individual with the environment, that is, on the need for it to adapt to changes. k. In the face of deficient sensory functions, the CNS compensates for the altered function, establishing new connections to other richer areas for information processing (Neural Substitution Phenomena in Sensory Deprivations) [77].

l. Auditory Processing, involves a deployment of neurochemical transformations, at the level of the auditory cortex, that occur when it comes to prosecuting auditory information.

m. Auditory processing, ie the analysis and synthesis of such information, and associated neurocognitive functions are based on functional functional mechanisms (neurotransmission, functional networks), natural qualities and capacities (cerebral plasticity, functional learning, phenomena of substitution). Of the CNS

n. The Central Auditory Processing Deficit will consequently imply, a disturbance in this processing, whose basic pathophysiological sustenance, consequently affects the hearing abilities [78].

o. CAPD may present with sensorineural hearing loss and patients should be carefully selected for which selection criteria were indicated [79-82].

p. Effective intervention should be applied consistently with the principles of neuroscience and functional learning. In this sense, the importance of intensive training to enhance plasticity and cortical reorganization in a multidisciplinary context is pointed out.

q. Hearing aids are the means of rehabilitation of hearing and discrimination that is lost due to hearing problems; Each type of pathology needs a different type of signal processing. The DPAC is not included in the programming of digital hearing aids, nor are there guides for signal processing or adjustment of hearing aids, despite the need to respond to the demands for improvement in verbal communication that these patients have.

r. In the intervention area, in these patients, the administration of digital technology, with hearing aids incorporating: adaptive multiband directionality, noise management, binaural coordination, wireless connection, provide the user with efficient perceptual resources, And actively stimulating listening skills, in repeated opportunities, of daily life:

i. Improvement to understand in noisy environment [83].

ii. Improvement to stay focused on an activity if there are other sounds in the environment.

iii. Improvement of the auditory attention, to maintain it or to divide it. 
iv. Improvement for the location of the sound source

v. Improved difficulty in following fast speech

vi. Improvement to understand the phone.

s. In patients with CAPD and Neurosensorial hearing loss, the digitalized acoustic signal technology allows the adaptation of these equipment according to the individual needs of the loss, while at the same time collaborating beneficially: facilitating, favoring stimulating compensatory and / or complementary processes of auditory information that Should be taken into account when processing at higher levels.

Finally note that digital technology must know the advances in neurosciences and the latter must incorporate that, for its development: collaborating, Facilitating and stimulating new challenges and discoveries. They are not replaced, but are required and complement each other. Only from an ethical attitude of the trained and trained professional, when this knowledge is applied, will depend on meeting the objective of both: improving the quality of life of patients.

\section{Reference}

1. American Speech-Language-Hearing (1996) Association Task Force on Central Auditory Processing Consensus development Central auditory processing, Current status of research and implications for clinical practice. American Journal of Audiology.

2. Audilogists Desk (1998) IH Gustav Mueller, James W, Hall. San Diego -London, UK.

3. Marilyn L Pinheiro, Marilyn L Pinheiro, Frank E Musiek (1987) Assessment of Central Auditory Disfunction. Foundations and clinical correlates.

4. Auditory Neuropathy (2011) C Abe L Garotta, S Pinheiro (articleSeptember 2000) Auditio: Revista Electrónica de Audiología. Vol. 1. 2001.

5. Avaliacao Do Processamento Auditivo (1998) Profe. Eliane Schochat Universidad do Sao Paulo, Brazil.

6. Atteintes centrales de l'audition R. Biboulet. A. Uziel U. Bordeaux Francia (1996).

7. (1998) Auditory Processing in Language Development and Language Disorders Christine Sloan Ph.D.

8. Chermak G, Musiek F (2003) Auditory Training: Principles and approaches for remediating and managing auditory processing disorders. Seminars in Hearing.

9. Auditory processing disorders: It s not just kids who have them T. Bellis (2003) The Hearing Journal.

10. American Academy of Audiology (2003) Speech Understanding. Cognitive Processing \& The Elderly.

11. Auditory processing in children (2003) Stollman M. Doctoral Dissertacion, University of Nijmegen.

12. Jane Baran (2002) Auditory processing disorders can negate the benefits of binaural amplification. The Hearing Journal (Agosto).

13. Bellis TJ (2008) Treatment of (Central) Auditory Processing Disorders en Valente M, Hosford-Dunn, H, Roesser RJ. Audiology Treatment. Ed. Thieme. ( $\left.2^{\text {nd }} e d n\right)$.
14. Blanco JL, Serra V (2005) The development of language in the child. Paper presented in the course: Verbal and nonverbal tests in the auditory deficit and printed in the didactic materials of the same. Ministry of Education of the Community of Madrid.

15. Barrio Tarnawiecki C (2000) Development of fetal auditory perception: Prenatal stimulation. Pediatric. Topics for review 3(2): 11-15.

16. Central Auditory Processing Disorders from Science to Practice (1999) Teri James Bellis. Connecticud Center for Auditory Processing Contens.

17. Brad A Stach(1998) Clinical Audiology. Central Auditory Processing Disorder. Sandra Cleveland.

18. Childrens Speech, Language and Hering History (1998) University of Miami.

19. Central Auditory Speech Test Chapter VI (1999).

20. Frank E Musiek William F, Rintelmann (2001) Contemporary Perspectives in Hearing Assessment.

21. Castillo MP, Roland PS (2007) Disorders of the Auditory System, at Roeser RJ, Valente M, Hosford-Dunn H Audiology Diagnosis ( $2^{\text {nd }} \mathrm{Edn}$ ).

22. JimDurkel, Kate Moss (1998) Central Auditory Processing and Auditory Neuropathy Disorders. Texas

23. Dillon H (2012) Hearing Aids. Boomerang Press \& Thieme (2 $\left.2^{\text {nd }} e d n\right)$

24. Bellis T (2003) Developing deficit-specifying plans for individuals with auditory. Processing Disorders. Seminars in Hearing.

25. Aminoff M (1999) Electro diagnosis in clinical neurology 3 edicion.

26. Evaluation of the Theory of the Next Activation in People with Normal Hearing and with Auditive Deterioration, Takayanagi and Noffingsr (2001) Ear and Hearing.

27. Fox K (1995) The critical period for long term potentiation in primary sensory cortex. Neuron 15 485-488.

28. Graniere Deferre C, Lecaunet JP, Cohen H, Busnel MC (1985) Feasibility of prenatal hearing test. Acta Otolaryngol 421: 93-101.

29. Griffiths TD, Banion DE, Warren JD (2000) Disorders of the auditory brain in Rees, A Palmer AR, The Oxford Handbook of Auditory Science. The Auditory Brain. Vol 2 (edn), Oxford University Press.

30. Jack Katz (2000) Handbook of Clinical Audiology.

31. Hall JW (1992) III Handbook of auditory evoked responses. Allyn \& Bacon, Boston, USA.

32. Jack Katz (1999) High-frecuency audiometry study with normal audiological subjects. Revista Brasileira Handbook of Clinical Audiology ( $4^{\text {th }}$ edn $)$

33. Jack Willeford (1998) Handbook of Central Auditory Processing Disorders in Children.

34. Carlos Molinari Marotto (1998) Introducción a los modelos cognitivos de la compresión del lenguaje. (edn), Eudeba.

35. E Schochat (2004) Insights for management of processing disorders. The Hearing Journal Octubre.

36. Juan Narbona, Claude Chevrie-Muller, El lenguaje del nino Desarrollo normal, evaluación y trastornos (2001) Elsevier Masson ( $2^{\text {nd }}$ edn).

37. Jusczyk PW (1997) The discovery of spoken language. MIT Press.

38. King AJ, Moore DR (1991) Plasticity of auditory maps in the brain. TINS, 14(1): 31-37.

39. Kaas JH (1991) Plasticity of sensory and motor maps in adult mammals. Annu Rev Neurosc 14: 137-167. 
40. Kruger B, Kruger FM (2020) Future Trends in Hearing Aid Fitting Strategies: With a View Towards. en Valente, M Strategies for Selecting and Verifyng Hearing Aid Fittings. Thieme.

41. Kuhl PK, Williams KA, Lacerda F, Stevens KN, Lindblom B (1992) Linguistic experience alters phonetic perception in infants by 6 month of age. Science 255: 606-608.

42. Kral A, Tillein J (2006) Brain plasticity under cochlear implant stimulation. de Møller, AR Cochlear and Brainstem Implants, (edn), Karger, p. 89-108.

43. Kral A, Tillein J, Heid S, Hartman, R, Klinke R (2005) Postnatal cortical development in congenital auditory deprivation. Cerebral Cortex 15: 552-562.

44. Kral A, Tillein J, Heid S, Hartmann R, Klinke R (2000) Congenital auditory deprivation reduces synaptic activity within the auditory cortex in a layer-specific manner. Cerebral Cortex. 10: 714-726.

45. Kaga K (2009) Central Auditory Pathway Disorders. Springer.

46. Lecanuet JP (1998) Foetal responses to auditory and speech stimuli. En Slater, A Perceptual development: visual, auditory, and speech perception in infancy. Psychology Press.

47. San Mateo (2001) Living and Working With A Central Auditory Processing Disorder. (CAPD) Judith W Paton, Audiologist.

48. Learning Disabilities Association (1997) American Speech Language Hering Association.

49. La Coclea (2001) Fisiologia y Patología, Hamblet Suarez - Ricardo Velluti.

50. Christine Sloan (1997) Language, Language Learning, and Language Disorder: Implications for central Auditory Processing.

51. Musiek FE, Weihing JA, Oxholm VB (2007) Anatomy and physiology of the central auditory nervous system: A clinical perspective. Cap 3 de Roeser, RJ, Valente, M, Hosford-Dunn, H Audiology Diagnosis $\left(2^{\text {nd }}\right.$ edn), Thieme.

52. Moore DR, Kitzes LM (1985) Projections from the cochlear nucleus to the inferior colliculus in normal and neonatally cochleablated gerbils. J Comp Neurolo 240: 180-195.

53. Baran (2002) Managing auditory processing disorders in adolescents and adults. Seminars in Hearing.

54. Musiek FE, Weihing JA, Oxholm VB (2007) Anatomy and Physiology of the Central Auditory Nervous System: A Clinical Perspective enRoeser, RJ, Valente M, Hosford-Dunn, H Audiology Diagnosis, Thieme, ( $\left.2^{\text {nd }} e d n\right)$.

55. España (2001) Neuropatía Auditiva Infantil. Dra. Maria Cruz Tapia. Madrid, spain.

56. Subhash C Bhatnagar, Orlando J Andy (1996) Neuro sciencie for the Study of Communicative Disorders.

57. Convention (2003) Memory, Interaction \& Integration Processes in the Elderly. American Academy of Audiology.

58. M Woldorff (1995) Neural Systems Mediating Selective Atencion S Hillyard.

59. Frank. Musiek, Jane A Baran, Marilyn L Pinheiro, Medical Center Neuroaudiology Case Studies.
60. Charles I Berlin (1995) Neurotramision y Perdida Auditiva. Ciencia Básica, Diagnostico y Manejo. Nueva Orleans, Luisiana.

61. J Jerger, Susan Jerger (1996) Presbiacusisan others age related aspects.

62. Pujol R, Lavigne Rebillard M, Uzile A (1991) Development of the human cochlea. Acta Otolaryngol 74: 383-391.

63. Perani D, Dehaene S, Grassi F, Cohen L, Cappa S, et al. (1996) Brain processing of native and foreign languages. Neuroreport Obtenido de:Rauschecker, JP Plasticidad de la corteza auditiva: Una comparación con otros sistemas sensoriales.

64. Processamento Auditivo Central Manual de avaliaçāo. LilianeDesgualdo Pereira. Eliane Schochat.

65. Proccessamento Auditivo Electrofisiología \& Psicoacustica.Dr. AntonioMariaClaret Marra de Aquino. (2002) Sao Paulo Brazil.

66. Gotzens Busquets, Silvia Marro Cosials, Antonia M (1999) Prueba de la valoracion de la percepcion auditiva. Explorando los sonidos y el lenguaje.

67. Quantifyng the Relation between Speech Quality and Speech Intelligibility (1996) Jill Preminger Diannej Van Tasell, University of Minessota, USA.

68. Michael F Dorman (2003) Speech Perception by Adults. Audiological Foundations.

69. Seminars in Hering (1998) Auditory Training and C.A.P.D Musiek, Shochat, 19(4).

70. Galambos R (2000) Suppressión of auditory nerve activity by stimulation of efferent fibers to cochlea Journal of Neurophisiology.

71. Stach BA, Loiselle LH, y Jerger JF (1992) Special hearing aid considerations. In ederlypatienswuithauditoy processing disorders. Ear \& Hearing.

72. Salesa E, Perelló E, Bonavida A (2005) Tratado de Audiología. Elsevier, Masson.

73. Schaub A (2008) Digital Hearing Aids. Thieme.

74. Stach BA (2007) Diagnosis AuditoryProcessing Disorders in Adults. enRoeser, R.J., Valente, M., Hosford-Dunn, H Audiology Diagnosis. Thieme, $\left(2^{\text {nd }}\right.$ edn $)$.

75. Sao Paulo (2000) Ten Indispensable Principles for Dispensing to Elders. Tratado de ORL Otologia Doencas, Brazil.

76. Trastornos Centrales de la Percepción Auditiva.M. Schminky and J Baran (1999) Departament of Communication Disorders. University Massachusetts.

77. Bellis TJ (2002) When the brain can t hear. Unraveling the mystery of Auditory. Processing Disordes. Pocket books.

78. C Sloan (1990) What Are Auditory Processing Difficulties in Children? Singular Publications.

79. What does handedness have to do with Brain Lateralizacion (2001) Cerebral Cortex, 11 (2).

80. Robet Keish (2002) Is evaluating auditory processing disorders in jour scope of practice? The Hearing Journal.

81. Venema TH (2006) Compression for Clinicians. Thomson. (2 $\left.2^{\text {nd }} e d n\right)$. 
(C) This work is licensed under Creative

DOI:10.19080/GJ0.2017.08.555730

\section{Your next submission with Juniper Publishers will reach you the below assets}

- Quality Editorial service

- Swift Peer Review

- Reprints availability

- E-prints Service

- Manuscript Podcast for convenient understanding

- Global attainment for your research

- Manuscript accessibility in different formats

( Pdf, E-pub, Full Text, Audio)

- Unceasing customer service

Track the below URL for one-step submission https://juniperpublishers.com/online-submission.php 